\title{
CONTRIBUTION TO THE PHYSIOLOGY OF THE STOMACH
}

\author{
XLVI. GASTRIC SECKETION DURING FEVER
}

JACOB MEYER, M.S., M.D., SEYMOUR J. COHEN, S.B.

AND

A. J. CARLSON, Ph.D.

CHICAGO

\section{Beaumont ${ }^{1}$ was first to observe that}

In febrile diathesis or predisposition from whatever cause... the villous coat becomes red and dry, at other times pale and moist and loses its smooth and healthy appearance; the secretions become greatly vitiated, greatly diminished, or entirely suppressed, and mucous coat scarcely perceptible, the follicles flat and fiaccid, with secretions insufficient to protect the nervous papillae . . . When there are corresponding symptoms of disease, as dryness of the mouth, thirst, accelerated pulse, etc., no gastric juice can be extracted, not even on the application of alimentary stimulus. Drinks received are immediately absorbed or otherwise disposed of, none remaining in the stomach ten minutes after being swallowed. Food taken in this condition of the stomach remains undigested for twenty-four to forty-eight hours or more, increasing the derangement of the whole alimentary canal and aggravating the general symptoms of disease.

Clinical and experimental evidence confirms these early observations of Beaumont. Thus Gluzinski, ${ }^{2} 1888$, noted that not only is there a diminution of the quantity of gastric juice, but that during the entire duration of an infectious fever the gastric juice showed an absence of acid, and that with the cessation of fever, or somewhat later, acid reappeared. During chronic fevers there was no apparent diminution of acid; Gluzinski therefore concluded that the diminution of gastric juice was less influenced by elevation of temperature than by infection.

Sassecki ${ }^{3}$ noted that the quantity of acid was not always diminished during fever, and that if dyspepsia was present before the onset of fever, it in itself might be the cause of the diminished secretion.

Uffelman, ${ }^{4}$ in an analysis of the vomitus of eight children during fever, always found a diminished secretion of gastric juice.

Grünfelder, ${ }^{5}$ in a series of experiments on two dogs, observed the effect of infection on gastric juice by means of the Pawlow pouch.

* Submitted for publication Dec. 1, 1917.

* From the Hull Physiological Laboratory of the University of Chicago.

1. Beaumont, W.: Experiments and Observations on the Gastric Juice and Physiology of Digestion, 1833.

2. Gluzinski, L. A.: Deutsch. Arch. f. klin. Med., 1888, 42, 145.

3. Sassecki: Cited from Gluzinski, Footnote 2.

4. Uffelman: Die Diët in den acute fieberhaften Erkrankungen, 1877.

5. Grünfelder : Ztschr. f. exper. Path. u. Therap., 1914, 16, 141. 
Gastric secretion was markedly reduced in quantity; free and total hydrochlorid were also reduced; pepsin remained constant.

Nichols ${ }^{6}$ says there is usually a diminution or total suppression of hydrochloric acid in various fevers, while pepsin is apparently little reduced.

Stockton" says that "the examinations of stomach contents in fever patients yield contradictory results and consequently are not always easily interpreted. The secretion may be but little impaired; more often there is a deficiency in hydrochloric acid, with less deficiency in the secretion of ferments.

It is thus seen that most observers report a diminished gastric secretion and a lowered acidity in fevers.

We have undertaken to renew the study of the changes in gastric secretion during fever in order to determine the mechanisms involved in the changes.

Procedure.-We prepared a number of dogs with Pawlow accessory stomachs. A period of ten days to three weeks was allowed each dog for recovery before we commenced our work.

The dogs were fed a standard quantity (from 150 to $200 \mathrm{gm}$.) of cooked meat and as much water as desired. The gastric juice was then collected at hourly intervals for five hours. In addition, the juice was collected one hour before feeding. The temperature of the animal was taken hourly during the period of secretion and the next morning following the experiment, so that we were sure that we were dealing with normal dogs.

Analysis of Gastric Juice.-One c.c. of the total quantity of gastric juice secreted was titrated on the same day for free and total hydrochloric acid. Pepsin was determined by diluting 1 c.c. of gastric juice with 10 c.c. tenthnormal hydrochloric acid and the amount of digestion calculated by the Mett's method.

Chlorids.-Van Slyke's method was followed, but we used 1 c.c. of gastric juice because we found that during fever the quantity of juice secreted was so small as to necessitate the use of small amounts in our determinations.

\section{CHANGES IN GASTRIC SECRETION PRODUCED BY FEVER}

Procedure.-The experiments were conducted as follows: Gastric juice was collected for one hour to obtain the amount of the continuous secretion; at the end of this period the temperature was recorded.

An intravenous injection of either sodium nucleate (10 c.c. of a 10 per cent. solution) or of killed culture of $B$. prodigiosus was then given, and after five or ten minutes the animal was given from 150 to $200 \mathrm{gm}$. of meat. At times the animal would refuse to eat. On such occasions forced feeding was resorted to, the meat being placed on the back of the tongue. With each meal 150 c.c. of water was given.

In several instances it was noted that the dogs vomited the food about one and one-half hours after the injection of the nucleate or the $B$. prodigiosus. When this occurred, the food, which was always undigested, was fed to the animal again.

6. Nichols: Am. Jour. Med. Sc., 1911, 142, 93.

7. Stockton, C. G.: Diseases of the Stomach, New York, 1914, p. 217. 
The results are briefly summarized in the accompanying Table 1, and Figure 1, $\mathrm{A}$ and $\mathrm{B}$.

Table 1 shows that in a series of experiments conducted on three dogs the changes produced in the gastric secretion were remarkably constant. The volume was reduced. Thus, with normal temperature the volume was 27,30 and 85.5 c.c. in Dogs 2,5 and 10 , respectively. In fever, with temperature of $105 \mathrm{~F}$., the volume was reduced to 10.4 c.c., 5.5 c.c. and 7.1 c.c.

Total acid and free acid were markedly reduced.

Pepsin was increased in two dogs, and diminished in one. The increase is apparently dependent on volume.

Chlorids are practically constant. We wish to emphasize this fact here in striking contrast to the change in the total and free acid. The secretion is mucous and ropy in character.

We may, therefore, conclude from the foregoing that during fever there are definite changes in the gastric secretion which are chiefly a diminution of volume, diminished free and total hydrochloric acid, a percentage increase in pepsin, and a nearly constant percentage of chlorids. We wish to note that these changes are present only during the febrile period, and that the next morning, the animals' temperature being normal, the gastric secretion was again normal.

It is worthy of special emphasis that the injection of sodium nucleate or $B$. prodigiosus produces marked disturbances in addition to elevation of the temperature. Thus diarrhea, mucous and bloody stools occurred in most of the dogs. Severe chills and severe prostration were often present, yet the following day the temperature was normal, the animal apparently well and the flow of gastric secretion normal. Only when our control experiments showed a return to normal did we repeat the experiment on the same animal.

The fact that in five experiments on one dog a killed culture of $B$. prodigiosus produced results identical with those following sodium nucleate indicates that there is nothing in the drugs or toxins used which might interfere or alter gastric secretion, but that it is the fever and its reaction which are the basis of the results.

\section{MECHANISM INVOLVED IN THE CHANGES OF GASTRIC SECRETION DURING FEVER}

(a) Rôle of Heat or Temperature Elevation.-In a recent communication by Meyer and Carlson ${ }^{8}$ the effect of external heat was proved to be a factor in the depression of hunger contractions. Salle, ${ }^{9}$ by elevat-

8. Meyer \& Carlson: Am. Jour. Physiol., 1917, 44.

9. Salle: Verhandl. d. 28 Versamml. d. Gesellsch. f. Kinderh., 1911, 72; Jahrb. f. Kinderh., 74, 627. 
TABLE 1.-Summary of Experiments and Controls on Three Dogs, Showing the Effect of Fever on Gastric Secretion

\begin{tabular}{|c|c|c|c|c|c|c|c|c|c|c|c|c|c|}
\hline \multirow{3}{*}{$\mathrm{Hr}}$. & \multicolumn{5}{|c|}{$\begin{array}{c}\text { Dog 2, Fed a Standiard } \\
\text { Diet of } 130 \mathrm{Gm} \text {. Meat }\end{array}$} & \multicolumn{4}{|c|}{$\begin{array}{c}\text { Dog 5, Fed a Standard } \\
\text { Diet of } 200 \mathrm{Gm} \text {. Meat }\end{array}$} & \multicolumn{4}{|c|}{$\begin{array}{l}\text { Dog 10, Fed a Standard } \\
\text { Diet of } 200 \mathrm{Gm} \text {. Meat }\end{array}$} \\
\hline & \multicolumn{3}{|c|}{$\begin{array}{c}\text { Normal } \\
\text { Av. } 7 \text { Exper. }\end{array}$} & \multicolumn{2}{|c|}{$\begin{array}{c}\text { Fever }^{*} \\
\text { Av. } 5 \text { Exper. }\end{array}$} & \multicolumn{2}{|c|}{$\begin{array}{l}\text { Normal } \\
\text { Av. } 8 \text { Exper. }\end{array}$} & \multicolumn{2}{|c|}{$\begin{array}{c}\text { Fever* } \\
\text { Av. } 9 \text { Exper. }\end{array}$} & \multicolumn{2}{|c|}{$\begin{array}{c}\text { Normal } \\
\text { Av. } 7 \text { Exper. }\end{array}$} & \multicolumn{2}{|c|}{$\begin{array}{c}\text { Fever } \\
\text { Av. } 5 \text { Exper. }\end{array}$} \\
\hline & Tem. & & $\begin{array}{l}\text { Vol. } \\
\text { C.c. }\end{array}$ & Temp. & $\begin{array}{l}\text { Vol. } \\
\text { C.c. }\end{array}$ & Temp. & $\begin{array}{l}\text { Vol. } \\
\text { C.c. }\end{array}$ & $\begin{array}{l}\text { 'Temp. } \\
\text { F. }\end{array}$ & $\begin{array}{l}\text { Vol. } \\
\text { C.c. }\end{array}$ & Temp. & $\begin{array}{l}\text { Vol. } \\
\text { C.e. }\end{array}$ & Temp. & $\begin{array}{l}\text { Vol. } \\
\text { C.c. }\end{array}$ \\
\hline 1 & 101. & & 6.7 & 104:5 & 1.8 & 101.7 & 7.3 & 104.9 & 0.9 & 101.5 & 24.0 & 104.8 & 1.3 \\
\hline 2 & 101. & & 6.3 & 106.1 & 2.2 & 101.6 & 6.6 & 105.5 & 0.9 & 101.4 & 19.8 & 105.9 & 1.4 \\
\hline 3 & 101. & & 5.2 & 105.7 & 2.1 & 101.7 & 6.1 & 105.4 & 1.0 & 101.5 & 16.6 & 105.6 & 1.3 \\
\hline 4 & 102. & & 4.7 & 105.1 & 2.6 & 101.7 & 5.4 & 105.3 & 1.3 & 101.6 & 13.1 & 104.8 & 1.9 \\
\hline 5 & 101. & & 4.1 & 103.7 & 1.7 & 101.8 & 4.6 & 104.1 & 1.3 & 101.5 & 11.9 & 104.4 & 1.2 \\
\hline T'ota & & & 27.0 & $\ldots .$. & 10.4 & $\ldots \ldots$ & 30.0 & $\ldots .$. & 5.5 & ..... & 85.5 & $\ldots .$. & 7.1 \\
\hline \multirow{2}{*}{\multicolumn{2}{|c|}{ 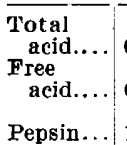 }} & \multicolumn{2}{|c|}{$\begin{array}{l}0.3854 \% \\
0.3151 \%\end{array}$} & \multicolumn{2}{|c|}{$0.1039 \%$} & \multicolumn{2}{|c|}{$0.4272 \%$} & \multicolumn{2}{|c|}{$0.1422 \%$} & \multicolumn{2}{|c|}{$0.4968 \%$} & \multicolumn{2}{|c|}{$0.0350 \%$} \\
\hline & Pepsin... & \multicolumn{2}{|c|}{$1.85 \mathrm{Mm}$} & \multicolumn{2}{|c|}{$2.64 \mathrm{Mm}$} & \multirow{2}{*}{\multicolumn{2}{|c|}{$\begin{array}{l}1.90 \mathrm{Mm} . \\
0.511 \% \mathrm{Cl} \text {. }\end{array}$}} & \multirow{2}{*}{\multicolumn{2}{|c|}{$\begin{array}{l}3.10 \mathrm{Mm} . \\
0.459 \% \mathrm{Cl}\end{array}$}} & \multirow{2}{*}{\multicolumn{2}{|c|}{$\begin{array}{l}2.3 \mathrm{Mm} . \\
0.495 \% \mathrm{Cl}\end{array}$}} & \multirow{2}{*}{\multicolumn{2}{|c|}{$\begin{array}{l}1.8 \mathrm{Mm} . \\
0.416 \% \mathrm{Cl} .\end{array}$}} \\
\hline \multicolumn{2}{|c|}{ Chlorids. } & \multicolumn{2}{|c|}{$0.495 \% \mathrm{Cl}$} & \multicolumn{2}{|c|}{$0.480 \% \mathrm{Cl}$} & & & & & & & & \\
\hline
\end{tabular}

* Injection of sodium nucleate.

+ Injection of B. prodigfosus.

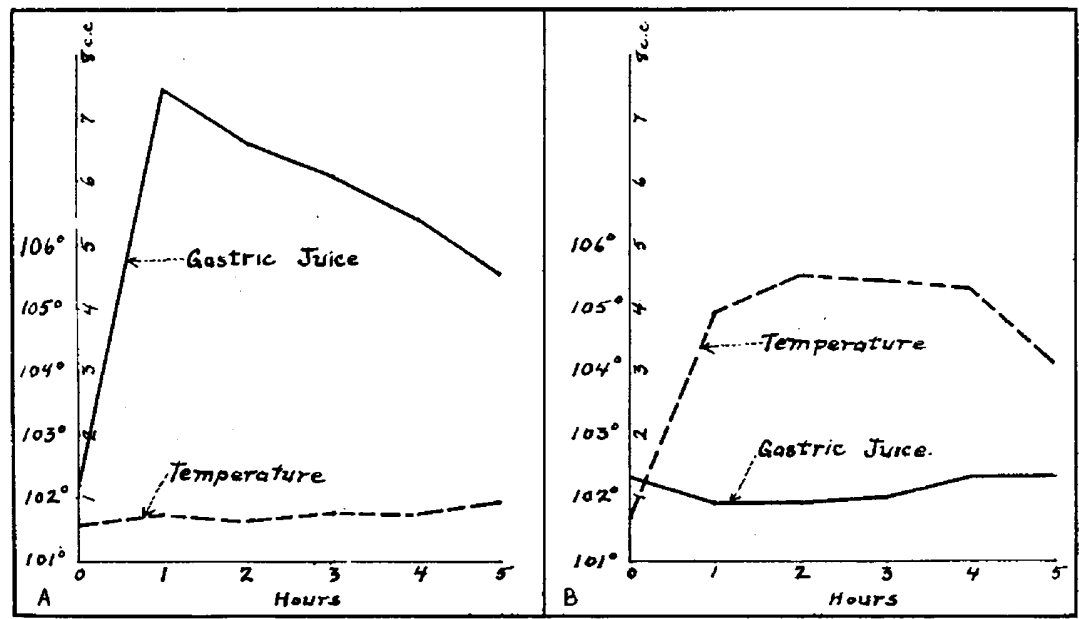

Fig. 1.- $A$, Composite chart of eight experiments (on Dog 5) showing the volume of gastric juice secreted after a meal of $200 \mathrm{gm}$. of boiled meat. Temperature normal.

$B$, Composite chart of nine experiments (on Dog 5) showing changes in gastric secretion during fever produced by injection of sodium nucleate or $B$. prodigiosus. Food, $200 \mathrm{gm}$. boiled meat. 
ing the external temperature, produced a condition simulating diarrhea in young dogs and reports a diminished volume; diminished free and total acid of the gastric juice. Salle fed his animals milk only, and therefore his results are not conclusive.

We determined the effect of elevating the temperature of the dogs by external heat, employing the method used by Meyer and Carlson. ${ }^{\mathrm{s}}$ By using a stronger electric current we were able to obtain a temperature in the cage varying from 45 to $64 \mathrm{C}$.

The normal temperature was first recorded, the animal placed in the hot box for one hour and the juice collected; at the end of this period the dog was fed. The animal was kept in the box for two hours longer, the juice being collected separately each hour. The animal was then removed to the room and the gastric juice collected for two hours at normal room temperature. A series of three experiments on one dog were thus conducted.

\section{RESULTS}

Table 2 and Figure 2, A and B, show the marked alteration in the character of the gastric secretion produced by elevating the temperature of the $\operatorname{dog}$ by means of external heat. The results are almost identical with the results produced by fever itself. A very striking fact is the entire absence of secretion on removal of the animal from the hot box, even though the body temperature fell rapidly to normal. The gastric secretion was normal again within twenty-four hours.

The animal becomes extremely prostrated for one to two hours after an exposure in the hot box. Restlessness, dyspnea, rapid pulse and extreme exhaustion are present. Salivation is pronounced, and this is a striking feature when compared with the decrease in gastric juice.

We may therefore conclude that temperature elevation produced by external heat induces the same changes in gastric secretion as are produced by fever, experimental or infectious. This is probably the condition of gastric secretion in cases of sunstroke.

(b). Effect of Fever Syndrome.-Does the fever or temperature elevation complex abolish the psychic factor, impair the function of the secretagogues or depress the gastric gland cells directly?

The striking similarity of the results obtained during actual fever and in the experiments of temperature elevation caused by external heat at once suggests the possibility of the entire change being due to failure of the psychic factor. Thus Pawlow" says that "in the occasional illness of our experimental animals there is an augmented or a diminished activity of the peptic glands as contrasted to the normal," and he believes that the change in the secretion is "of a reflex nervous nature." We are able at present to differentiate between the psychic and the chemical factors by the use of gastrin. ${ }^{11}$ When gastrin is

10. Pawlow: The Works of the Digestive Glands, 1910, p. 241.

11. Keeton and Koch: Am. Jour. Physiol,, 115, 37, 481. 
TABLE 2.-Summary of Experiments (with Controls) on the Influence of Thermic Frver on Gastric Secretion

\begin{tabular}{|c|c|c|c|c|c|}
\hline \multirow{3}{*}{ Hour } & \multicolumn{5}{|c|}{ Dog 2.-Fed a Standard Diet of $200 \mathrm{Gm}$. Meat } \\
\hline & \multicolumn{2}{|c|}{$\begin{array}{c}\text { Normal } \\
\text { Average } 8 \text { Experiments }\end{array}$} & \multicolumn{3}{|c|}{$\begin{array}{l}\text { Fever } \\
\text { Average } 3 \text { Experiments }\end{array}$} \\
\hline & $\begin{array}{c}\text { Body } \\
\text { Temperature, } \\
\text { F. }\end{array}$ & $\begin{array}{c}\text { Volume } \\
\text { Gastric Juice, } \\
\text { C.c. }\end{array}$ & $\begin{array}{c}\text { Body } \\
\text { Temperature, } \\
\text { F. }\end{array}$ & $\begin{array}{l}\text { Volume } \\
\text { Gastric Juice, } \\
\text { C.c. }\end{array}$ & $\begin{array}{c}\text { Temperature } \\
\text { of Box, } \\
\text { C. }\end{array}$ \\
\hline 1 & 101.6 & 7.3 & 106.6 & 1.3 & 48 \\
\hline 2 & 101.7 & 6.6 & 108.5 & 0.4 & 47 \\
\hline · & 101.6 & 6.1 & 105.9 & 0.1 & 45 \\
\hline 4 & 101.7 & 5.4 & 103.9 & None & 21 \\
\hline 5 & 101.8 & 4.6 & 103.0 & None & 21 \\
\hline Total & ..... & 30.0 & ..... & 1.8 & \\
\hline Total acid....... & \multirow{4}{*}{$\begin{array}{l}0.5 \\
0.5 \\
3.8 \\
0.5\end{array}$} & $272 \%$ & \multicolumn{3}{|c|}{$0.2066 \%$} \\
\hline Free acid... & & $.3610 \%$ & \multicolumn{3}{|c|}{$0.0942 \%$} \\
\hline Pepsin.. & & $.90 \mathrm{Mm}$ & \multicolumn{3}{|c|}{$2.6 \mathrm{Mm}$} \\
\hline Chlorid.... & & $\% \mathrm{Cl}$ & \multicolumn{3}{|c|}{$0.472 \% \mathrm{Cl}$} \\
\hline
\end{tabular}

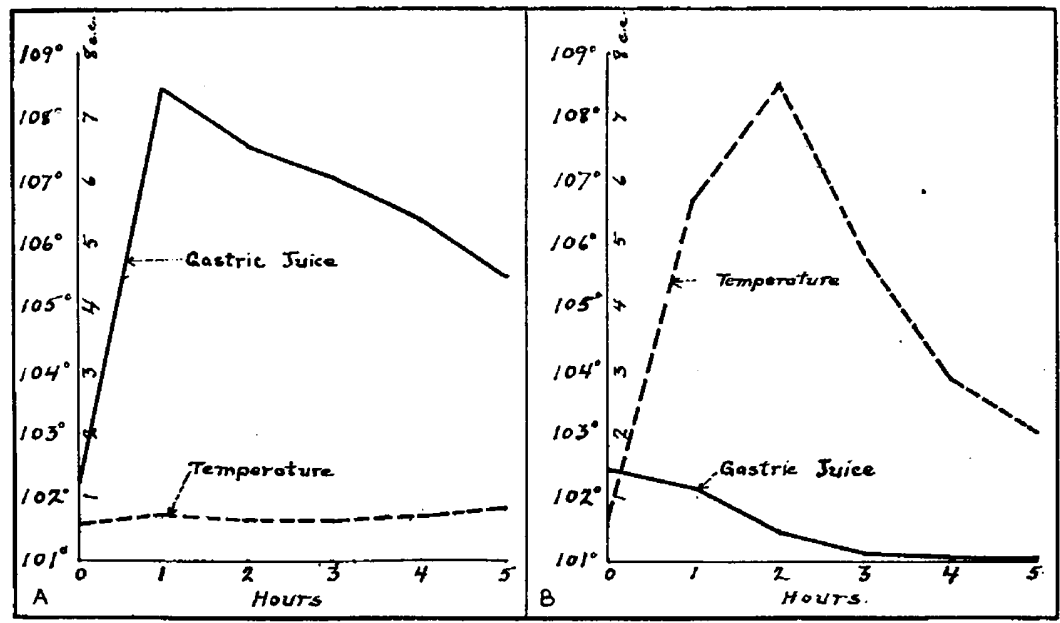

Fig. 2.- $A$, Composite chart of eight experiments (on Dog 5) showing the volume of gastric juice secreted after a meal of $200 \mathrm{gm}$. of boiled meat. Temperature normal.

$B$, Composite chart of three experiments on Dog 5 , showing change in volume of gastric juice during temperature elevation caused by external heat. Food, $200 \mathrm{gm}$. boiled meat. 
injected subcutaneously it gives rise to a definite secretion of gastric juice, in which the psychic factors play no rôle at all. We therefore employed gastrin to determine the direct response of the gastric glands during fever.

Procedure.-We first determined the normal response of our animals to subcutaneous injection of 1 c.c. of gastrin. Having secured our normals we determined the gastrin action during fever. Our procedure was generally as in the preceding experiments. The dog was allowed to secrete normally for one hour (continuous secretion), then sodium nucleate or B. prodigiosus was injected intravenously. At the end of the second hour 1 c.c. of gastrin was injected subcutaneously. The juice was then collected at hourly intervals for from three to four hours after the injection of gastrin. In some cases no analysis of the chlorids was made because of the small quantity of secretion.

In studying the effects of temperature elevation due to external heat on the secretion caused by gastrin, we employed the methods detailed on page 358 . with the addition that 1 c.c. of gastrin was injected.

\section{RESULTS}

In a series of five experiments on two dogs in which fever was produced by nucleate and prodigiosus, and in twelve experiments on five dogs, in which a temperature elevation as high as from 105 to 112 was caused by external heat, the changes produced in the secretion caused by the injection of 1 c.c. of gastrin were striking and uniform. The volume was diminished; at times there was no secretion at all. The total and free acid were reduced. The chlorids were practically constant (Tables 3 and 4, Figs. 3 and 4, A and B).

These experiments prove that during fever produced by the injection of sodium nucleate or $B$. prodigiosus, or during temperature elevation caused by external heat, gastrin is unable to induce the normal secretion of gastric juice. The changes in the gastrin secretion are exactly the same as those found in the gastric juice secreted in response to food during fever.

\section{DISCUSSION}

What other factor must be considered in the alteration of gastric secretion during fever?

Salle ${ }^{9}$ believed that the heat of the body itself was the most important factor. . Grünfelder ${ }^{5}$ considers the temperature of the blood together with the secretogogues as equally important. Pawlow ${ }^{10}$ holds that the changes are of a reflex nervous nature. Our experiments demonstrate beyond doubt the fact that the heat of the body is an important factor in causing an alteration in gastric secretion.

Furthermore, since, as we have proved that gastrin when injected subcutaneously during fever is unable to induce its normal secretion, it follows that any gastrin formed from the food substances eaten during fever would also be unable to induce a gastric secretion. Our results with gastrin point to a definite depression of the gastric gland cells, 
which may be explained by the action of "toxins" elaborated during fever. It is conceivable that the toxins present might have a direct action on the glands. We believe that the greatest factor in the alteration of gastric secretion during fever is a change in the cells of the glands of the stomach. We are inclined to this view because of our

TABLE 3.-Summary of Experiments (with Controls) on Two Dogs, Showing the Effect of Injection of 1 C.c. Gastrin on the Secretion of Gastric Juice During Fever

\begin{tabular}{|c|c|c|c|c|c|c|c|c|}
\hline & Hour & $\begin{array}{c}\text { Temper- } \\
\text { ature, } \\
\text { F. }\end{array}$ & $\begin{array}{l}\text { Vol- } \\
\text { ume, } \\
\text { C.c. }\end{array}$ & $\begin{array}{l}\text { Total } \\
\text { Acid, per } \\
\text { Cent. }\end{array}$ & $\begin{array}{c}\text { Free } \\
\text { Acid, per } \\
\text { Cent. }\end{array}$ & $\begin{array}{c}\text { Ohlorids, } \\
\text { per } \\
\text { Cent. }\end{array}$ & $\begin{array}{l}\text { Pep- } \\
\text { sin, } \\
\text { Mm. }\end{array}$ & Remarks \\
\hline \multirow{4}{*}{$\begin{array}{l}\text { Dog 5.-Normal; } \\
\text { secretion pro- } \\
\text { duced by } 1 \text { c.c. } \\
\text { gastrin. } \\
\text { Average } 3 \text { exper- } \\
\text { iments }\end{array}$} & $\mathbf{x}$ & 101.4 & 15.6 & 0.4771 & 0.4314 & $\ldots$. & 1.0 & Clear \\
\hline & 2 & 101.4 & 5.3 & 0.5044 & 0.4557 & 0.499 & 1.1 & Clear \\
\hline & 3 & 101.5 & 1.6 & 0.3312 & 0.2188 & $\ldots .$. & 1.4 & Clear \\
\hline & 4 & 101.6 & 1.1 & $\ldots \ldots$ & $\cdots \cdots$ & $\ldots \ldots$ & $\cdots$ & Clear \\
\hline Total......... & $\ldots$ & ..... & 23.6 & & & & & \\
\hline \multirow{4}{*}{$\begin{array}{l}\text { Dog } 5 .- \text { Fever; } \\
\text { secretion pro- } \\
\text { duced by } 1 \text { c.c. } \\
\text { gastrin. } \\
\text { Average } 2 \text { exper- } \\
\text { iments }\end{array}$} & 1 & 106.2 & 0.6 & 0.0912 & None & 0.431 & 4.3 & Mucus \\
\hline & 2 & 105.6 & 1.0 & 0.1824 & 0.0639 & $\ldots .$. & 3.3 & \\
\hline & 3 & 104.8 & 1.2 & 0.1915 & 0.0406 & $\ldots .$. & 4.6 & Mucus \\
\hline & 4 & 103.4 & 0.5 & $\cdots$ & $\cdots \cdots$ & $\cdots \cdots$ & $\cdots$ & Mucus \\
\hline Total......... & $\cdots$ & $\ldots \ldots$ & 3.3 & & & & & \\
\hline \multirow{4}{*}{$\begin{array}{l}\text { Dog 9.-Normal; } \\
\text { secretion pro- } \\
\text { duced by I c.c. } \\
\text { gastrin. } \\
\text { Average } 3 \text { exper- } \\
\text { iments }\end{array}$} & 1 & 101.6 & 18.9 & 0.4497 & 0.3889 & 0.477 & 1.7 & Clear \\
\hline & 2 & 101.3 & 13.8 & 0.4770 & 0.4132 & $\ldots$. & 1.2 & Clear \\
\hline & 3 & 101.4 & 4.7 & 0.2764 & 0.1395 & $\ldots .$. & 2.4 & Clear \\
\hline & 4 & 101.6 & 1.9 & $\ldots \ldots$ & ...... & $\ldots$. & $\cdots$ & Clear \\
\hline Total........ & $\cdots$ & $\ldots$. & 39.3 & & & & & \\
\hline \multirow{4}{*}{$\begin{array}{l}\text { Dog 9. - Fever; } \\
\text { secretion pro- } \\
\text { duced by } 1 \text { c.c. } \\
\text { gastrin. } \\
\text { Average } 3 \text { exper. } \\
\text { inients }\end{array}$} & 1 & 105.6 & 1.4 & 0.0517 & None & 0.451 & 4.0 & Mucus \\
\hline & 2 & 105.3 & 2.4 & 0.0669 & None & $\ldots$. & 3.5 & Mucus \\
\hline & 3 & 104.6 & 1.5 & 0.0726 & None & $\ldots$. & 4.2 & Mucus \\
\hline & 4 & 103.5 & 1.0 & $\ldots \ldots$ & ...... & $\cdots \cdots$ & $\ldots$ & Mucus \\
\hline Total......... & ... & $\ldots .$. & 6.3 & & & & & \\
\hline
\end{tabular}

results with gastrin. Although the mechanism of the action of gastrin is not definitely understood, recent work would seem to indicate that it has a direct action in the cells of the gastric glands. Thus in a personal communication from Luckhardt, Koch and Keeton on "Effect oi Atropin on Gastric Stimulation of Stomach," they have noted that, "any dose of atropin sufficient to inhibit gastric flow under food stimulation will reduce the secretory activity following gastrin stimulation. 
It is always possible, however, even after maximal doses of atropin, doses that are definitely toxic to the animal, to cause a flow of juice by increasing the dose of gastrin." These findings tend to confirm our view. We suggest that in fever gastrin is unable to induce its normal gastric secretion because of alteration in the gland cells. We believe that the same mechanism explains the failure of gastric secretogogues

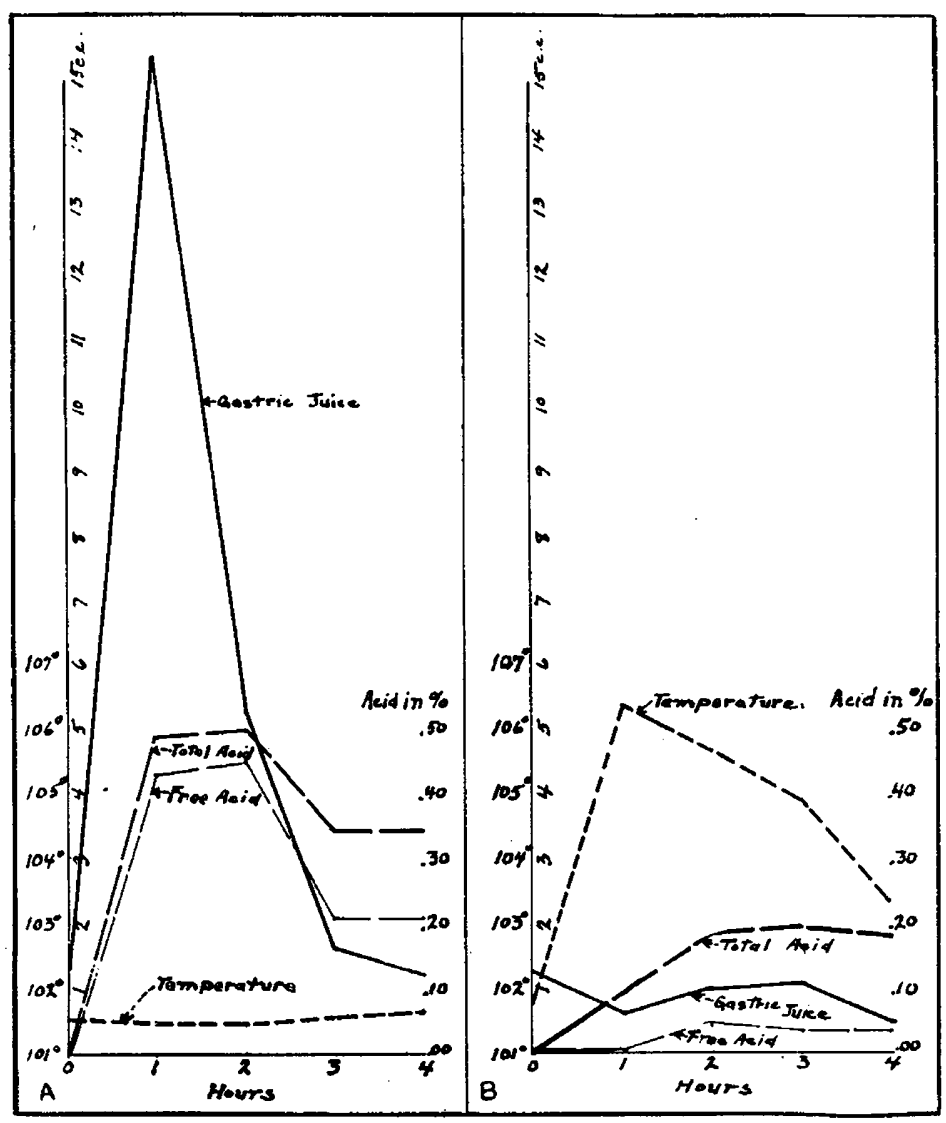

Fig. 3.- $A$, Composite chart of three experiments showing character of secretion produced by injection of 1 c.c. gastrin subcutaneously, during normal temperature.

$B$, Composite chart of two experiments showing character of gastric secretion produced by gastrin during fever caused by sodium nucleate and $B$. prodigiosus.

produced by food eaten during fever to cause a secretion. The most important factor in the alteration of gastric secretion during fever is a depression of the gland cells. These cell changes are transitory in character, and are probably in the nature of a cloudy swelling. 
TABLE 4.-Summary of Experiments (With Controls) on Five Dogs,

Showing the Effect of Injection of 1 C.c. Gastrin on the Secretion of Gastric Juice During Thermic Fever

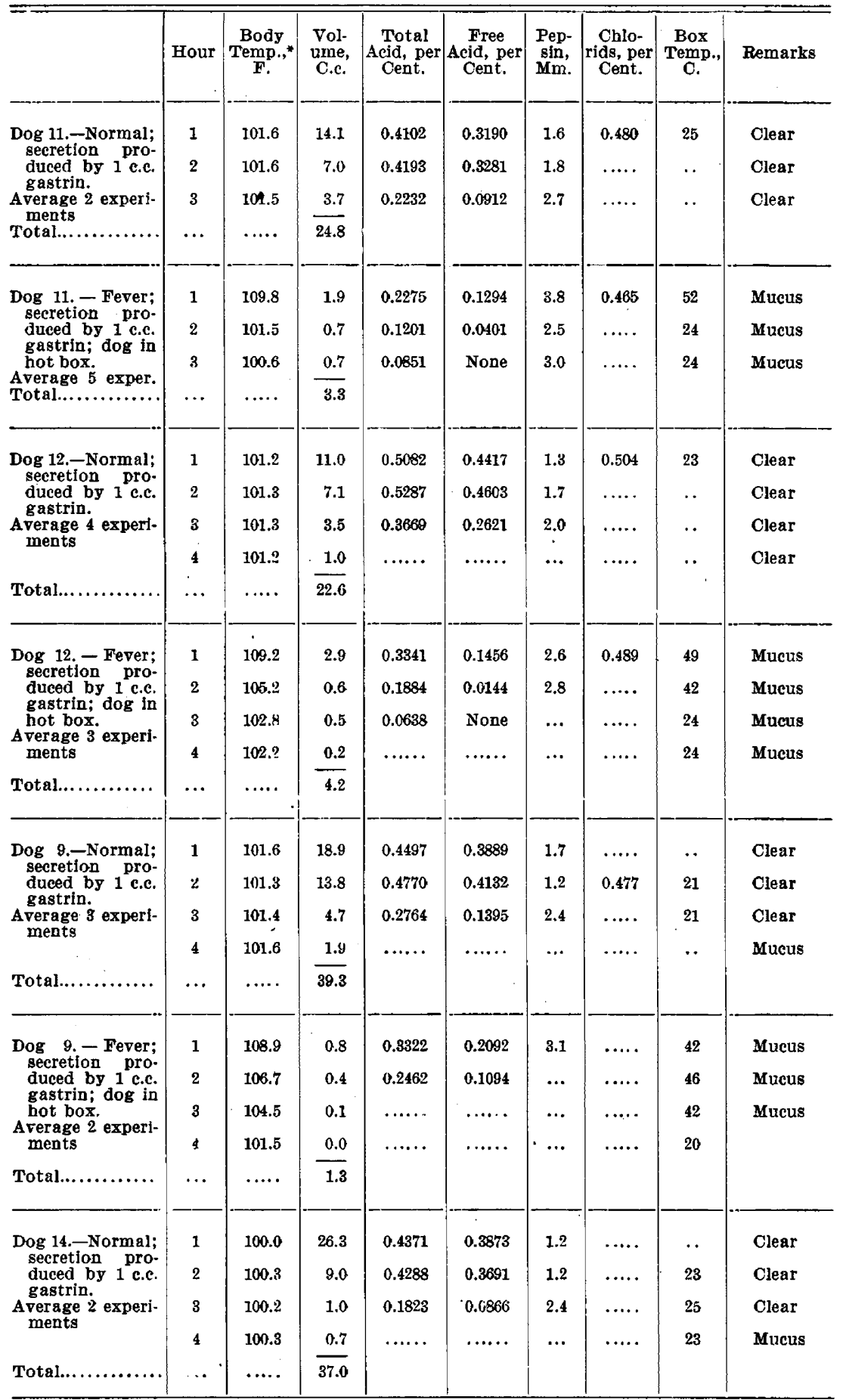

* The fever was produced by elevating the external temperature by use of a hot box. 
TABLE 4.-Summary of Experiments (With Controls) on Five Dogs, SHOWING THE EFFect OF INJECTION OF 1 C.c. Gastrin on the Secretion of Gastric Juice During Thermic Fever-

(Continued)

\begin{tabular}{|c|c|c|c|c|c|c|c|c|c|}
\hline & Hour & $\underset{\text { Temp.," }}{\text { Body }}$ & $\begin{array}{l}\text { Vol- } \\
\text { ume, } \\
\text { C.c. }\end{array}$ & $\begin{array}{c}\text { Total } \\
\text { Acid, per } \\
\text { Cent. }\end{array}$ & $\begin{array}{c}\text { Free } \\
\text { Acid, per } \\
\text { Cent. }\end{array}$ & $\begin{array}{l}\text { Pep- } \\
\text { sin, } \\
\mathbf{M m} \text {. }\end{array}$ & $\begin{array}{l}\text { Chlo- } \\
\text { rids, per } \\
\text { Cent. }\end{array}$ & $\begin{array}{c}\text { Box } \\
\text { Temp., } \\
\text { C. }\end{array}$ & Remarks \\
\hline $\begin{array}{l}\text { Dog 14. - Fever; } \\
\text { secretion pro- } \\
\text { duced by I c.c. } \\
\text { gastrin; dog in } \\
\text { hot box. } \\
\text { Average I experi- } \\
\text { ment }\end{array}$ & $\begin{array}{l}1 \\
2 \\
3 \\
4\end{array}$ & $\begin{array}{r}109.0 \\
105.1 \\
108.4 \\
102.5\end{array}$ & $\begin{array}{l}0.7 \\
0.6 \\
0.1 \\
0.0\end{array}$ & $\begin{array}{l}0.3372 \\
0.1368 \\
\ldots \ldots \\
\ldots \ldots\end{array}$ & $\begin{array}{l}0.1824 \\
\text { None } \\
\ldots \ldots \\
\ldots \ldots\end{array}$ & $\begin{array}{l}3.1 \\
4.0 \\
\cdots \\
\cdots\end{array}$ & $\begin{array}{l}\ldots \ldots \\
\ldots \ldots \\
\ldots \cdots \\
\ldots \cdots\end{array}$ & $\begin{array}{l}35 \\
40 \\
45 \\
24\end{array}$ & $\begin{array}{l}\text { Mucus } \\
\text { Mucus } \\
\text { Mucus } \\
\text { Mucus }\end{array}$ \\
\hline 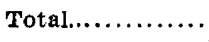 & $\cdots$ & $\cdots$ & 1.4 & & & & & & \\
\hline $\begin{array}{l}\text { Dog } 16 .- \text { Normal; } \\
\text { secretion pro- } \\
\text { duced by } 1 \text { c.c. } \\
\text { gastrin. } \\
\text { Average } 3 \text { experi- } \\
\text { ments }\end{array}$ & $\begin{array}{l}1 \\
2\end{array}$ & $\begin{array}{r}101.3 \\
101.4 \\
101.4 \\
101.4\end{array}$ & $\begin{array}{l}20.0 \\
20.7 \\
17.7 \\
11.2\end{array}$ & $\begin{array}{l}0.4740 \\
0.5013 \\
0.4922 \\
0.4588\end{array}$ & $\begin{array}{l}0.4122 \\
0.4466 \\
0.4375 \\
0.4132\end{array}$ & $\begin{array}{l}1.7 \\
1.8 \\
1.9 \\
1.7\end{array}$ & $\begin{array}{l}\cdots \cdot \\
\ldots \ldots\end{array}$ & $\begin{array}{l}\cdots \\
23 \\
23 \\
23\end{array}$ & $\begin{array}{l}\text { Clear } \\
\text { Clear } \\
\text { Clear } \\
\text { Clear }\end{array}$ \\
\hline Total.............. & $\cdots$ & $\cdots \cdots$ & 69.6 & & & & & & \\
\hline $\begin{array}{l}\text { Dog 16. - Fever; } \\
\text { secretion pro- } \\
\text { duced by } 1 \text { c.c. } \\
\text { gastrin; dog in } \\
\text { hot box. } \\
\text { Average } 1 \text { exper. } \\
\text { Total............... }\end{array}$ & $\begin{array}{l}1 \\
2 \\
3 \\
\cdots\end{array}$ & $\begin{array}{r}109.9 \\
103.2 \\
102.2 \\
\ldots \ldots\end{array}$ & $\begin{array}{l}1.2 \\
0.3 \\
0.0 \\
1.5\end{array}$ & $\begin{array}{l}0.1641 \\
0.1732\end{array}$ & $\begin{array}{l}0.0821 \\
0.0274 \\
\ldots \ldots\end{array}$ & $\begin{array}{l}2.5 \\
\ldots\end{array}$ & … & $\begin{array}{l}48 \\
26 \\
25\end{array}$ & $\begin{array}{l}\text { Mucus } \\
\text { Mucus }\end{array}$ \\
\hline
\end{tabular}

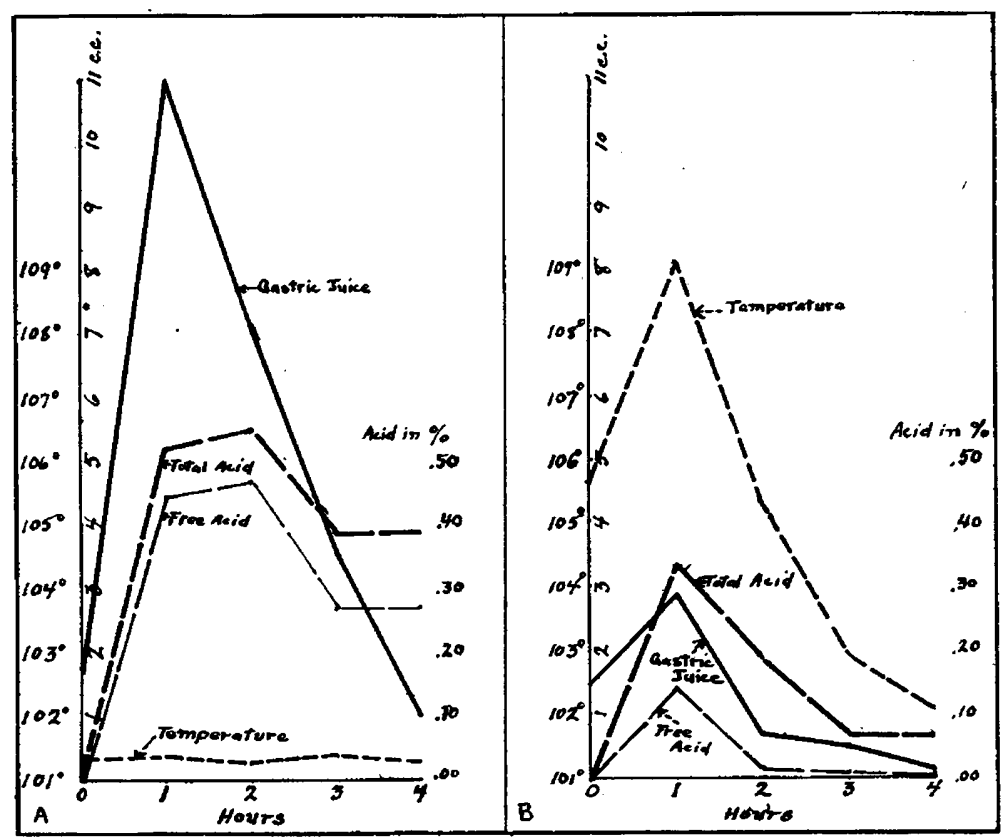

Fig. 4.- $A$, Composite chart of four experiments on Dog 12, showing character of secretion produced by subcutaneous injection of gastrin.

$B$, Composite chart of three experiments on Dog 12, showing character of secretion produced by gastrin during temperature elevation caused by external heat. 
In view of the marked changes in gastric secretion in fever, these studies should be extended to other digestion secretions, especially those of the pancreas and the intestinal mucosa.

\section{SUMMARY}

1. During fever gastric secretion is diminished in volume and in total and free acid. The percentage of chlorids is constant or only slightly reduced and pepsin is relatively increased. The secretion is ropy and mucous in character.

2. External heat itself when sufficient to induce temperature elevation of from 2 to $4 \mathrm{~F}$., will cause the same changes in gastric juice as produced by fever.

3. Gastrin is unable to induce a secretion of gastric juice during fever, as well as in a condition of temperature elevation due to external heat.

4. It is suggested that during fever, toxins are elaborated having a direct depressor action on the cells of the stomach so that they fail to react to the secretory nerve impulses and to the secretogogues.

We wish to thank Dr. F. C. Koch for his kindness in furnishing us with the gastrin preparations used in our experiments. 